\title{
MENUJU DISTRIBUSI RASKIN YANG ADIL (STUDI PELAKSANAAN PROGRAM RASKIN DI KABUPATEN GRESIK TAHUN 2015)
}

\author{
Sri Kamariah \\ Fakultas Ilmu Administrasi Negara Universitas Dr. Soetomo, Surabaya \\ email: srikamariyah@gmail.com
}

\begin{abstract}
The purpose of this study is to find out about the distribution of Raskin and fakror-Perform analysis of what factors influence the implementation Raskin and Conducting an analysis of alternative management model or pattern Raskin forward, to ensure a fair distribution in the District Sidayu Sukorejo village, district Gresik. The method is descriptive qualitative method, in which the main instrument is the researcher's own research. Source of data used is the primary data source and secondary data relating to the circumstances of the empirical implementation of policy. In this study, the authors also use survey research to obtain primary data on the distribution of Raskin. on the basis of existing data, the authors attempt to describe I illustrate a systematic, factual and accurate information on the facts, properties and relationships between phenomena. The results showed that using the frameworks of Edward III, bureaucratic structure, communication, and disposition of resources, implementation of program distribution Raskin conducted by Bulog in targeting encountered an error target (mistargeting) despite the relatively low levels, are often not appropriate because it concerned certain groups, rationing is not in accordance with the Policy Raskin Raskin is to share equally on all citizens. Recommendations include the data necessary to analyze back associated RTS$P M$ Raskin is not on target, RTS By rule-PM receives Raskin as much as $15 \mathrm{~kg}$ per month. In fact in the field, the distribution is often not appropriate number. Raskin quota should not be generalized, to be adjusted by the number of family members RTS-PM
\end{abstract}

Keywords: Distribution Raskin, public policy. 


\section{PENDAHULUAN}

Raskin adalah salah satu program pemerintah untuk membantu masyarakat yang miskin dan rawan pangan, agar mereka mendapatkan beras untuk kebutuhan rumah tangganya. Program raskin tersebut merupakan salah satu program penanggulangan kemiskinan termasuk dalam Kluster I tentang Bantuan dan Perlindungan Sosial. Instruksi presiden Nomor 8 tahun 2008 tentang kebijakan perberasan mengintruksikan Menteri dan Kepala Lembaga Pemerintah Non Departemen tertentu, serta Gubernur dan Bupati/Walikota seluruh Indonesia untuk melakukan upaya peningkatan pendapatan petani, ketahanan pangan, pengembangan ekonomi pedesaan serta stabilitas ekonomi nasional.

Secara khusus kepada Perum Bulog diinstruksikan untuk menyediakan dan menyalurkan beras bersubsidi bagi kelompok masyarakat miskin dan rawan pangan yang penyediannya mengutamakan pengadaan beras dari gabah petani dalam negeri. Penyaluran beras bersubsidi bagi kelompok masyarakat miskin bertujuan untuk mengurangi beban pengeluaran rumah tangga miskin (RTM), disamping itu program ini dimaksudkan untuk meningkatkan akses masyarakat miskin dalam pemenuhan kebutuhan pangan pokoknya sebagai salah satu hak dasar masyarakat. Hal ini merupakan salah satu program pemerintah baik pusat maupun daerah yang penting dalam peningkatan ketahanan pangan nasional. Program Raskin dapat dicapai melalui Koordinasi antara instansi/lembaga terkait, baik di tingkat pusat maupun daerah, koordinasi dilaksanakan mulai dari perencanaan, pelaksanaan, pengawasan dan pengendalian dengan mengedepankan peran penting partisipasi masyarakat.

Tidak seluruh masyarakat Indonesia yang berhak atas Raskin, hanya mereka yang tergolong miskin dan rawan pangan di daerah tertentu mendapat hak untuk menerima Raskin. Sebaran Rumah Tangga Sasaran Penerima Manfaat (RTS-PM) ditentukan berdasarkan Data BPS PPLS 2008 pada Tahun 2011 sampai dengan Bulan Mei 2012 dan berdasarkan Basis Data Terpadu (BDT) untuk Program Perlindungan Sosial yang bersumber dari PPLS 2011 hasil pendataan BPS dan dikelola oleh Tim Nasional Percepatan Penanggulangan Kemiskinan (TNP2K) pada Bulan Juni 2012 sampai dengan sekarang. Untuk memilih kelompok yaitu sesuai kriteria yang ditetapkan data keluarga miskin dan rawan pangan dikumpulkan dari berbagai sumber seperti Kelurahan, LSM, dan sebagainya. Data tersebut dibawa ke Musyawarah Desa untuk diteliti kebenarannya dan dikoreksi, apabila ada data yang rangkap atau yang tidak sesuai, kemudian Musyawarah Desa memilih dan menetapkan keluarga yang termasuk paling miskin dan rawan pangan sesuai jumlah plafon yang disediakan. Pemilihan dapat menggunakan sistem rangking sehingga hanya mereka yang benar-benar paling miskin dan rawan pangan saja yang dipilih. Hasil musyawarah Desa perlu diketahui oleh seluruh masyarakat.

Jumlah beras yang diberikan kepada setiap keluarga miskin sesuai pedoman adalah 15 Kg beras setiap bulan dengan harga Rp. 1.600/kg. Harga tersebut adalah harga di titik distribusi. Biaya dari titik distribusi ketempat masing-masing ditanggung oleh masing-masing penerima. Raskin dibagikan setiap bulan di titik distribusi, waktu pembagian setiap bulan sesuai jadwal yang disepakati. Titik distribusi yaitu lokasi yang disepakati yang diusahakan dekat dengan penerima. Lokasi tersebut adalah di Kelurahan atau di Balai Desa. Raskin dibagikan oleh petugas yang ditunjuk di titik distribusi yang bersangkutan Penanggung jawab pembagian Raskin di Desa/Kelurahan adalah Kepala Desa atau Lurah. Raskin berasal dari gudang Bolog/sub Divre Bolog, beras tersebut diangkut dari gudang oleh Satgas Raskin ke setiap titik distribusi. Satgas Raskin terdiri dari petugas Bulog/sub Divre Bulog/petugas Pemda atau yang ditunjuk. Dalam penyaluran beras untuk masyarakat miskin sering ditemui kendala-kendala, kendalanya bisa dari masyarakat bahkan dari aparaturnya itu sendiri. Jika ditemui para pengelola Raskin tersebut tidak jujur dan amanah dalam menjalankan tugasnya, dan uang Raskin tersebut tidak disetorkan kepada bulog hal ini sangat menghambat penyaluran Raskin bulan berikutnya dan yang menjadi korban adalah masyarakat. 
Kelancaran penyaluran Raskin sangat bergantung dari disiplin seluruh pelaku yang terlibat dalam Raskin. Salah satu yang terpenting adalah kelancaran pembayaran. Keluarga penerima harus lancar membayar uang beras pada petugas di titik distribusi. Petugas titik distribusi harus lancar dan segera menyetor uang hasil penjualan beras Raskin ke Bulog/sub Divre Bulog yang selanjutnya harus segera disetor ke pusat. Penundaan pembayaran hasil penjualan Raskin tidak dibenarkan, karena apabila ada ketidak lancaran dari salah satu titik distribusi tersebut akan menyebabkan keterlambatan penyaluran Raskin berikutnya, yang rugi adalah masyarakat. Pembayaran maupun kelengkapan administrasi Raskin harus menjadi prioritas utama sebagai upaya meningkatkan akuntabilitas.

Program Raskin ini sebenarnya diawali dengan Program Operasi Pasar Khusus Beras pada tahun 1998. Operasi ini merupakan tindak lanjut dari adanya krisis ekonomi pada pertengahan tahun 1997, disertai kemarau kering serta bencana kebakaran hutan dan ledakan serangan hama belalang dan hama wereng coklat yang telah menyebabkan penurunan produksi pangan secara nyata. Penurunan ini dipicu kenaikan harga pupuk dan obat pemberantas hama yang cukup tinggi.

Harga beras kemudian semakin meningkat naik sejak bulan Mei 1997 dan mencapai puncaknya sekitar Mei - Juni 1998, Menghadapi situasi ini, pemerintah telah memutuskan membentuk Tim Pemantau Ketahanan Pangan yang prinsipnya merupakan Food Crisis Center atau pusat penanggulangan krisis pangan. Langkah ini ditindak lanjuti dengan diadakannya Operasi Pasar Khusus Beras yang operasionalnya dilakukan oleh BULOG.

Penunjukan BULOG untuk melaksanakan program ini antara lain karena beberapa alasan seperti persiapan sarana perdagangan, sumber daya manusia, dan stok beras BULOG yang tersebar di seluruh Indonesia, dan mekanisme pembiayaan yang memungkinkan BULOG mendistribusikan terlebih dahulu berasnya, kemudian baru ditagihkan kepada pemerintah. Setiap tahunnya program OPK ini dievaluasi dan terus dilakukan penyempurnaan. Tahun 2002 program ini diganti menjadi program Raskin (beras untuk masyarakat miskin).

Program Raskin merupakan subsidi pangan sebagai upaya dari pemerintah untuk meningkatkan ketahanan pangan dan memberikan perlindungan pada keluarga miskin melalui pendistribusian beras yang diharapkan mampu menjangkau keluarga miskin,

Tujuan program Raskin adalah mengurangi beban pengeluaran rumah tangga miskin melalui pemenuhan sebagian kebutuhan pangan pokok dalam bentuk beras. Sasaran program Raskin tahun 2013 adalah berkurangnya beban pengeluaran 19.1 juta Rumah Tangga Miskin (RTM) berdasarkan data BPS, melalui pendistribusian beras bersubsidi sebanyak 15 $\mathrm{Kg} / \mathrm{RTM} /$ bulan selama 12 bulan dengan harga tebus $\mathrm{Rp} .1 .600$ per kg netto di titik distribusi.

Sasaran program Raskin Tahun 2013 adalah sesuai data RTS yang dikirimkan oleh TNP2K dengan identitas jelas, yaitu Kartu Perlindungan Sosial yang tertulis by name and by address dengan jatah $15 \mathrm{~kg}$ per KK selama 12 bulan. Dengan demikian ada beberapa KK yang dicoret dari daftar penerima Raskin. Program Raskin telah dilakukan di seluruh Indonesia, termasuk di Jawa Timur.

Tabel.1.1.

Data Jumlah Penerima Raskin Kabupaten Gresik per Bulan.

\begin{tabular}{|c|c|c|}
\hline Tahun & Jumlah Beras (TON) & Jumlah RTS \\
\hline $\mathbf{2 0 1 3}$ & 816,21 & 54.414 \\
\hline $\mathbf{2 0 1 4}$ & $9.740,64$ & 92.768 \\
\hline $\mathbf{2 0 1 5}$ & $1.116,26$ & 77.751 \\
\hline
\end{tabular}

Sumber: Bulog Divre Jawa Timur

Dari Tabel 1.1 terlihat pada tahun 2013 dengan adanya verifikasi KK yang berhak dari BPS untuk menerima raskin turun menjadi 77.751 RTM per KK, dengan PAGU 1.116,26 
ton per bulan, Jumlah yang diterima per Rumah Tangga Sasaran (RTS) $15 \mathrm{~kg}$ dengan harga tebus $\mathrm{Rp} 1.600$ per kilogram. Program Raskin di harapkan dapat berlangsung optimal di semua wilayah penerima Raskin, termasuk di wilayah di Desa Sukorejo Kecamatan Sidayu, Kabupaten Gresik.

Dari hasil penelitian awal, kebijakan Raskin belum berjalan sesuai dengan sasaran program. Pada kenyataannya implementasi kebijakan Raskin tidak selalu berpedoman penuh pada prosedur kebijakan karena tergantung pada kondisi dan situasi masyarakat setempat. Banyak pelaksanaan yang tidak sama dengan tujuan yang ada pada Pedoman Umum/Petunjuk Pelaksanaan Raskin. Penyimpangan yang kerap terjadi yaitu tidak tepatnya jumlah beras yang diperoleh para Rumah Tangga Miskin (RTM) penerima manfaat Raskin, yang seharusnya berdasarkan PAGU Raskin setiap RTM menerima beras sejumlah $15 \mathrm{~kg}$ tetapi yang diperoleh hanya sekitar $5 \mathrm{~kg}$ per RTM/RTS. Hal itu terjadi karena keterbatasan beras yang jumlahnya lebih sedikit dari jumlah warga yang menerima Raskin sehingga menyebabkan mayoritas masyarakat merasa senang namun sebagian kecil juga ada yang merasa tidak puas karnı tidak sesuai dengan kebutuhan mereka.

Distribusi Raskin hingga kini masih memunculkan beberapa permasalahan, ] busi Program Raskin di Desa Sukorejo Kecamatan Sidayu, Kabupaten Gresik belum tepat sasaran, belum tepat jumlah dan belum tepat waktu, Data RTS dari BPS dengan data penerima Raskin tidak sama, Akibat dibagi rata maka jumlah beras yang diterima RTM relatif sedikit, sehingga kurang bermanfaat bagi penerima.

\section{METODE PENELITIAN}

Pada prinsipnya penelitian ini menggunakan pendekatan yang berbasis pada qualitative reseacrh. Dengan pendekatan kualitatif diharapkan mampu menghasilkan suatu uraian mendalam tentang ucapan, tulisan dan/atau perilaku yang dapat diamati dari suatu individu, kelompok, masyarakat, suatu organisasi/komunitas dalam konteks tertentu yang dikaji dari sudut pandang yang utuh, komprehensif dan holisitik. Sebagaimana dinyatakan oleh Guba \& Lincoln (1989) bahwa penelitian kualitatif memang paling tepat untuk melaksanakan kegiatan penelitian yang bersifat eksploratif dan evaluatif, karena jenis dan desain penelitian pada pendekatan naturalistic pada umumnya relatif lebih leluasa dalam menjaring dan menetapkan variabel-variabel penelitian.

\section{HASIL DAN PEMBAHASAN}

\section{Program Raskin Desa Sukorejo Kecamatan Sidayu Kabupaten Gresik}

Penyaluran Raskin di Desa Sukorejo Kecamatan Sidayu berdasarkan surat Sekda Kabupaten Gresik. Berikut adalah isi surat Sekda Kabupaten Gresik Nomor 511.1/335 tanggal 1 Desember 2013 perihal Penyaluran Raskin Bulan Desember 2013:

1. Jadwal penyaluran beras Raskin bulan Desember 2013 akan dilaksanakan pada hari Senin tanggal 7 Desember 2013.

2. Tiap RTS akan menerima beras sebanyak $15 \mathrm{~kg}$ dengan harga jual $\mathrm{Rp} 1.600$ dan pembelian tunai.

3. Untuk pengambilan/penyaluran beras Raskin bulan Desember 2013 bagi kelurahan yang belum lunas tidak dapat dilayani/ditinggal dan pengambilan beras di gudang Bulog ditanggung sendiri oleh kelurahan tersebut. Untuk itu diminta segera melunasi HPB Raskin bulan November 2013.

4. Selanjutnya agar biaya langsir yang dari APBD Kabupaten Gresik tahun 2013 dapat berlaku efektif, maka diminta kepada kelurahan agar mengambil biaya langsir (Rp 60/kg). Dengan membawa surat tugas dan kwitansi yang dapat diambil di kecamatan Sidayu.

Disamping itu juga dilampirkan data RTS untuk Desa Sukorejo Kecamatan Sidayu. Berdasarkan data BPS (441 BTS) dan jumlah beras yang diterima $6.615 \mathrm{~kg}$. Selanjutnya setelah 
beras Raskin dan uang langsir sudah sampai di desa sukorejo, maka kelurahan membuat surat kepada para ketua RW untuk mengambil beras Raskin dan uang langsir di desa sukorejo. Kemudian RW menyerahkan kepada ketua RT masing- masing untuk dibagikan kepada RTS. Setelah satu minggu tiap-tiap RW membayar uang Raskin dari RTS Kasi.Kesra. desa sukorejo. (Bpk Muzayin) yang kemudian uang tersebut disetor ke Bulog lewat BRI.

Dari uraian di atas dapat disimpulkan bahwa kelurahan hanya berfungsi sebagai tempat transit penyaluran Raskin dari kecamatan/Bulog ke RTS dan sebagai koordinator untuk membayarkan ke Bulog yang selanjutnya dikelola oleh masing- masing RW dan RT untuk didistribusikan ke RTS.

\section{Implementasi Program Raskin Desa Sukorejo}

Pendekatan dalam implementasi program Raskin menggunakan pendekatan Top Down yang sangat umum. Dikenal dalam wacana Kebijakan Publik, padahal keputusan sering kali tidak selaras dengan materi yang diinginkan oleh masyarakat sebagai akibat dari gerak perubahan keinginan masyarakat lebih cepat dari respon aparat biokrasi terhadap perubahan itu. (Kendala administratif seringkali membuat aparat birokrasi terkesan bekerja lambat), perbedaan karakter sosial antara birokrat dengan masyarakat menyebabkan persepsi mereka berbeda terhadap satu persoalan yang sama.

Sungguhpun demikian Sabatier (Subarsono, 2005) juga mengemukakan dua kelemahan lain dari pendekatan top-down yaitu:

1. Sebuah kebijakan yang dirumuskan secara berkelanjutan walau secara jelas telah dirumuskan, menyulitkan pemerintah menguak nuansa persoalan baru yang berkembang dalam masyarakat.

2. Cenderung melahirkan proses kebijakan publik yang tidak demokratis, bahkan sangat mungkin melahirkan rezim politik yang otoritarian.

Pembahasan terhadap implementasi akan difokuskan pada isi dan lingkungan kebijakan dengan acuan Teori Merilee Grindle. Masing-masing bagian ini akan dibahas berdasarkan fenomena penelitian yang diamati. Proses analisis terhadap fenomena pengamatan dilakukan dengan proses triangulasi baik dari sumber informasi maupun isi informasi.

\section{Isi Kebijakan Program Raskin}

a. Pemahaman kepentingan RTS (Rumah Tangga Sasaran)

Hasil penelitian menunjukkan bahwa waktu yang terbatas pada saat tahap perencanaan menyebabkan program pelaksanaan Raskin terkesan "dipaksakan". Keterbatasan waktu tersebut turut mempengaruhi keberhasilan pelaksanaan masing-masing tahapan dan keseluruhan program. Dalam pentargetan ditemui adanya kesalahan sasaran (mistargeting) meskipun dalam tingkat yang relatif rendah. Hal ini terindikasi dari adanya rumah tangga tidak miskin yang menjadi penerima Raskin (leakage) dan adanya rumah tangga miskin yang belum menjadi penerima (undercoverage). Beberapa faktor yang diperkirakan melatarbelakangi kesalahan sasaran adalah:

1. Tidak meratanya kapasitas pencacah yang tidak ditunjang oleh pelatihan dan bimbingan yang memadai;

2. Cukup tingginya subyektivitas pencacah dan juga ketua-ketua SLS (Satuan Lingkungan Setempat) yang bertugas mendaftar rumah tangga miskin;

3. Prosedur penyaringan rumah tangga miskin (RTS) tidak dilakukan secara seksama;

4. Pencacah tidak selalu mendatangi rumah tangga yang dicacah;

5. Terdapat indikasi adanya penjatahan jumlah rumah tangga target sampai di tingkat rukun tetangga (RT);

6. Indikator kemiskinan yang digunakan kurang sensitif dalam menangkap kondisi sosial-ekonomi rumah tangga secara utuh; 
7. Konsep keluarga atau rumah tangga sasaran (RTS) Raskin tidak ditetapkan secara tegas.

Dari hasil pengamatan di lapangan menunjukkan bahwa:

1. Alokasi pentargetan kewilayahan sampai tingkat kecamatan relatif cukup baik, sesuai dengan jumlah penduduk miskinnya.

2. Pentargetan di tingkat RT atau RW menunjukkan hasil tingkat ketepatan sasaran yang bervariasi.

3. Terdapat indikasi bahwa pendaftaran rumah tangga miskin susulan kurang selektif.

Seperti halnya yang dikemukakan oleh ibu Suryono (ibu RW) :

"Iya, saya paham siapa-siapa yang seharusnya mendapat bantuan Raskin, yaitu orang miskin yang tidak mampu memenuhi kebutuhan hidup akan tetapi warga di sini semua minta jatah beras, jadi ya dibagi rata saja." (wawancara 1 Juli 2014)

Demikian juga yang dikemukakan oleh ibu Sukardi :

"Walaupun itu jatahnya orang miskin, tetapi daripada ribut-ribut ada yang iri ya baiklah dibagi rata"( wawancara 1 Juli 2014)

Kepentingan kelompok sasaran diakomodir dengan baik melalui tingkat RT ke tingkat RW. Lewat pertemuan-pertemuan bulanan, seperti yang dikemukakan oleh bapak Saimin selaku ketua RW :

"Sudah sering terjadi, masalah datang dari warga setiap nanti pertemuan di tingkat desa saya sampaikan di pertemuan itu, biasanya setiap bulan. Misalnya ada desa kalau berasnya item-item, nanti saya sampaikan di tingkat desa, nanti di tingkat desa menyampaikan ke kecamatan" ( wawancara 1 Juli 2014)

Seperti halnya yang dinyatakan oleh ibu Waliyah (warga RW III) :

"Kan bisa ngomong ke pak $R T$ dulu atau ke pak RW langsung, biasanya pak $R W$ itu menyampaikan ke pak Lurah" ( wawancara 1 Juli 2014)

Komentar ini dikuatkan oleh yang membidangi dan mengkoordinasi distribusi ditingkat desa yaitu bapak Muzayin selaku Kasi kesra menjelaskan bahwa:

"Penyaluran beras Raskin kewarga yang berhak mendapat program tersebut dibagi secara merata sehingga tidak terjadi keributan warga, proses pembagian beras raskin didata dengan dibagi ada yang mendapatkan daftar nama pokok,daftar nama gilir 1, 2 dan 3 dengan penyalurannya melalui dibagikan kupun sehingga pembagian itu merata. Sebenernya aturan itu tidak dibolehkan tetapi kita demi warga agar warga kita tidak terjadi ramai gara-gara beras raskin" (wawancara 1 Juli 2014)

Hasil wawancara tersebut, dapat disimpulkan bahwa sebenarnya masyarakat paham siapa sasaran Raskin (RTS) akan tetapi karena kondisi masyarakat, maka para pelaksana berdasarkan kesepakatan warga mengambil kebijakan untuk membagi rata jatah Raskin pada semua warga. Pembagian jatah Raskin secara merata ini sebetulnya telah memberikan gambaran bahwa terjadi kesalahan dalam proses pendataan terhadap keluarga miskin. Persoalan akan muncul apabila terjadi penambahan jumlah penduduk miskin di suatu wilayah. Ketika jatah Raskin didasarkan pada sistem alokasi maka akan terjadi mekanisme pengurangan jumlah beras yang diterima akan tetapi kemungkinan akan terjadi penurunan kualitas beras yang dibagikan.

Kebijakan Program Raskin bagi rumah tangga miskin diharapkan dapat menekan peningkatan proporsi penduduk miskin. Namun, tingkat kemiskinan akan semakin tinggi jika tingkat ketepatan semakin rendah. Sementara itu, masalah ketepatan sasaran sendiri dipengaruhi oleh mekanisme penentuan/identifikasi sasaran. Mengingat sasaran program adalah rumah tangga miskin, kriteria dan mekanisme penentuan atau pengukuran kemiskinan menjadi sangat penting, walaupun konsep dan pengukuran kemiskinan itu sendiri masih diperdebatkan oleh banyak kalangan. 
Pengukuran kemiskinan dapat dibedakan dalam dua tingkatan, ukuran kemiskinan makro dan mikro. Ukuran kemiskinan makro biasanya diperlukan untuk pentargetan wilayah (geographic targeting), sedangkan ukuran kemiskinan mikro dibutuhkan untuk sasaran rumah tangga/keluarga. Pemetaan kemiskinan (poverty mapping), baik yang dihasilkan oleh BPS untuk seluruh wilayah Indonesia menyediakan ukuran-ukuran kemiskinan untuk berbagai tingkatan wilayah dari provinsi sampai dengan desa/kelurahan, yang merupakan salah satu alat yang dapat digunakan untuk menentukan pentargetan kewilayahan. Sedangkan untuk pengukuran kemiskinan mikro, yaitu rumah tangga/keluarga, dibutuhkan suatu kriteria operasional yang dapat dengan mudah digunakan untuk mengidentifikasi siapa dan bagaimana orang miskin. Untuk tujuan tersebut, umumnya digunakan pendekatan karakteristik rumah tangga.

Selama ini, kriteria keluarga prasejahtera 2 dari Badan Koordinasi Keluarga Berencana Nasional (BKKBN) banyak digunakan dalam penentuan sasaran penerima bantuan. Namun, untuk penentuan sasaran penerima program Raskin kali ini, digunakan kriteria miskin dari Badan Pusat Statistik (BPS) yang ditentukan dengan menggunakan metode uji pendekatan kemampuan (proxy-means testing) dan didasarkan pada kerangka kerja kontekstual, yang berarti variabel kemiskinan untuk tiap kabupaten/kota tidak selalu sama.

\section{Manfaat Raskin yang diterima oleh RTS}

Hasil penelitian menunjukkan bahwa secara umum tingkat kepuasan penerima terhadap pelaksanaan Raskin adalah paling tinggi dibanding tingkat kepuasan aparat/tokoh desa/kelurahan atau kabupaten/kota. Meskipun demikian, penerima maupun aparat/tokoh di tingkat desa/kelurahan dan kabupaten/kota menilai sosialisasi merupakan aspek yang paling tidak memuaskan. Sedangkan cara pencairan Raskin merupakan aspek yang paling memuaskan. Hasil wawancara mendalam bukan penerima juga menunjukkan kondisi tingkat kepuasan yang tidak jauh berbeda.

Penelitian ini juga menunjukkan adanya perbedaan penilaian terhadap keberadaan Raskin. Sebagian aparat kurang setuju karena menganggap Raskin sebagai "program yang hanya memberi ikan, bukannya kail" Sebagian aparat lainnya setuju sepanjang pelaksanaannya tepat sasaran. Sementara itu, masyarakat penerima merasa terbantu dengan keberadaan Raskin dan mereka menilai keberadaan program tidak mempengaruhi etos kerja.

Pedoman umum Raskin menunjukkan bahwa tujuan program Raskin adalah mengurangi beban pengeluaran rumah tangga miskin melalui pemenuhan pembagian kebutuhan pangan pokok dalam bentuk beras. Hal tersebut sudah sesuai dengan yang dirasakan oleh warga seperti yang dikemukakan oleh pak Hengki (ketua RW) :

"Ya jelas bermanfaat sekali untuk warga disamping harganya murah ya apalagi situasi sekarang kan tidak menentu, ada yang kerjanya hanya pocokan saja, ada yang tukang bangunan. Ya jelas program ini bemanfaat sekali buat mereka-mereka" (wawancara 1 Juli 2014)

Demikian juga pernyataan dari ibu Waliyah

"Iya ahamdulillah, saya senang sekali ada Raskin ini, ya soalnya harganya itu yang

murah, pengeluaran per bulannya lebih irit. Ketimbang kita kalau beli beras yang ada di warung harganya sampai Rp 6.000 itu saja Cuma dapat 1 kg, kalau Raskin kan Rp

10.000 dapat $5 \mathrm{~kg}$ to.. Sebenarnya harganya Rp 9.000 yang seribu buat iuran beli plastik untuk mbungkusi berasnya" ( wawancara 1 Juli 2014)

Hasil dari wawancara tersebut dapat disimpulkan bahwa masyarakat (RTS) sangat senang, merasa mendapatkan manfaat, dan terbantu dalam pemenuhan kebutuhan pangan pokok

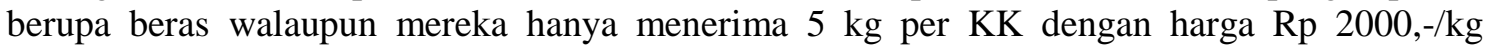
seharusnya menurut PAGU Raskin 2013 per KK mendapat $15 \mathrm{~kg}$ dengan harga Rp 1.600/kg. Meskipun demikian, sebagian besar RTS program Raskin merasa bahwa pembagian beras 
kepada warga miskin mempunyai manfaat minimal kebutuhan dalam satu minggu. Beberapa responden yang ditemui menyatakan bahwa program ini harus terus dijalankan dan kalau bisa penerimaan beras dapat tepat waktu dan tepat jumlah.

Wawancara dengan Kepala Desa Sukorejo Kecamatan Sidayu Kabupaten Gresik :

"Penyaluran raskin itu harus sesuai dengan prosedur dan aman bagi perangkat desa dan masyarakat supaya tidak terjadi gejolak gara-gara raskin, kami pemerintah desa harus membagi sesuai dengan data dari BPS yang sudah ada sejak dulu, tetapi ada masalah dilapangan terkait beras bulog yang sudah berbau dan masyarakat kalau sudah dapat beras dijual lagi ketengkulak khusus beras bulog, dan tengkulak tersebut dijual lagi kebulog, artinya ada mata rantai beras didistribusikan kemasyarakat tetapi masyarakat tidak mau konsumsi dikarenakan berasnya berbau membahayakan kesehatan sehingga dijual kembali" (wawancara 2 juli 2014).

Pernyataan kepala desa dikuatkan oleh warga RW 2 namanya tidak mau disebut :

"beras songko bulog niku ambune ora enak, mosok masyarakat diwei mangan beras seng ora genek dipangan, mangkane tak dol hasile adol tak tukokno beras seng lewih apik ben gak penyakiten, wes gak duwe loro-loroen yo opo pemerintah" artinya " Beras dari bulog itu berbau tidak enak, apakah masyarakat diberi makan beras yang tidak bisa dimakan, mangkanya saya jual hasilnya jual beras saya belikan beras yang lebih bagus sehingga tidak sakit-sakitan gimana pemerintah" (wawancara 2 Juli 2014)

Pernyataan koordinator dan penanggung jawab distribusi beras tingkat desa Bapak Muzayin menjelaskan bahwa:

"Pembagian beras raskin kami bagi dengan sistem gilir sehingga merata pembagian beras raskin di desa kami, masalah dijual kembali oleh warga itu hak warga kami terserah, yang penting mekanisme itu berjalan dengan baik tidak terjadi gejolak warga, saya sampaikan daftar nama penerima beras raskin di desa kami" (wawancara 2 Juli 2014)

\section{Perubahan kondisi RTS setelah mendapatkan Raskin}

Suatu program yang bertujuan mengubah sikap dan perilaku kelompok sasaran relatif lebih sulit diimplementasikan dari pada program yang sekedar memberikan bantuan kredit atau bantuan beras kepada kelompok masyarakat miskin (Subarsono :2005). Dengan adanya program Raskin, masyarakat yang tadinya tidak mampu membeli beras, diharapkan kemudian berubah menjadi terbantu dan mampu untuk membeli karena harganya relatif murah. Seperti yang dikemukakan oleh pak Saimin :

"Saya kira program ini kan program dari pusat dari pemerintah ya kepengennya masyarakat bisa mampu membeli beras yang harganya juga nggak terlalu mahal kan Cuma Rp 1.600/kg ketimbang mereka yang beli di warung kan nyampe Rp 7.000 an yah" ( wawancara 1 Juli 2014)

Demikian juga menurut Bapak Hengki :

"Kalau menurut saya perubahan yang ingin dicapai ya dalam hal perekonomian. Dengan adanya program ini, yang tadinya tidak mampu untuk memberi beras diharapkan akan mampu terbantu untuk membelinya" ( wawancara 1 Juli 2014)

Hasil wawancara dapat disimpulkan bahwa perubahan yang diinginkan dengan adanya program ini, bagi RTS adalah masyarakat mampu membeli beras untuk kebutuhan pangan sehari-hari. Hasil analisis pembagian manfaat tersebut memperlihatkan cukup besarnya variasi tingkat ketepatan sasaran, bahkan dalam satu wilayah kabupaten/kota yang sama, sehingga sulit untuk menarik kesimpulan secara umum tentang tingkat ketepatan sasaran Raskin . Dari hasil analisis pembagian manfaat tersebut di atas, tingkat ketepatan sasaran Raskin dapat dievaluasi, baik di tingkat kewilayahan maupun di tingkat rumah tangga. Namun demikian, perlu diperhatikan bahwa setiap ukuran yang digunakan dalam mengevaluasi ketepatan sasaran akan 
memberikan hasil yang berbeda. Keragaman pengukuran ketepatan sasaran dapat dijelaskan jika diketahui dengan tepat konsep dan metode pengukuran kemiskinan pembanding yang digunakan serta unit/tingkat analisisnya.

\section{Ketepatan sasaran Program Raskin Desa Sukorejo}

Penentuan RTS yang dapat menerima Raskin sudah diputuskan oleh kelurahan yaitu dari BPS, berupa kartu yang sudah ada nama dan alamatnya. Tetapi ada warga miskin yang tidak dapat Raskin. Sebaliknya warga yang cukup mampu mendapatkan kartu sehingga terjadi keresahan. Untuk mengatasi masalah ini ketua RW berperan dalam mengatur pembagian Raskin kepada warganya. Hasil wawancara dengan ketua RW II dan RW IV :

RW II warga yang mendapat Raskin $200 \mathrm{KK}$, jatah Raskin hanya 74 sak @ $15 \mathrm{~kg}$, Dengan musyawarah warga semua warga dapat $5 \mathrm{~kg}$ tiap $K K$. Lain halnya yang terjadi di $R$ W IV dimana $40 \%$ warga miskin yang seharusnya menerima Raskin tidak dapat kartu, padahal memperoleh BLT yang menunjukkan warga kurang mampu. Agar tidak timbul konflik, maka dibagi merata tapi untuk warga yang tidak dapat kartu dapat Raskinnya tidak tiap bulan, untuk warga yang dapat kartu memperoleh setiap bulan. ( wawancara 1 Juli 2014)

Hasil wawancara tersebut dapat disimpulkan bahwa data BPS dapat dikatakan tidak valid karena proses pendataannya tidak ada koordinasi dengan RT dan RW (menurut ketua RW III, ada warganya yang sudah tergolong mampu dapat kartu Raskin, sebaliknya yang miskin tidak dapat karena waktu pendataan RT dan RW tidak tahu), sehingga pengambilan keputusan untuk pembagian Raskin atas musyawarah warga dan diputuskan oleh ketua RW.

Secara umum, koordinasi dan komunikasi pelaksanaan Raskin dinilai lemah. Indikasinya antara lain: 1) dokumen dari pusat tentang Raskin terlambat atau bahkan tidak diterima pemda; 2) pendataan rumah tangga miskin dilakukan sebelum Inpres No. 12 Tahun 2005 tentang Pelaksanaan Bantuan Langsung Tunai kepada Rumah Tangga Miskin keluar; 3) Rakor tingkat menteri Bidang Kesra kurang tepat dalam menafsirkan Inpres tersebut, yakni tugas Departemen Dalam Negeri (Depdagri) sebagai koordinator pelaksanaan dan pengawasan berubah menjadi pengawasan dan penanganan pengaduan. Oleh karenanya, salah satu fungsi pemda sebagai kepanjangan tangan Depdagri untuk mengkoordinasikan pelaksanaan Raskin tidak dilakukan dan sebagian pemda merasa tidak dilibatkan secara resmi dalam pelaksanaan Raskin. Sebagian pemda juga mempertanyakan komitmen pemerintah pusat atas pelaksanaan politik desentralisasi dan otonomi daerah karena Raskin bersifat sentralistik dan dilaksanakan oleh institusi yang juga sentralistik (Bolog dan Kecamatan).

Sifat ketertutupan proses pendataan dan penetapan penerima Raskin dirasakan bertentangan dengan proses demokratisasi yang tengah dibangun. Dalam kaitan ini terdapat konflik antara larangan BPS mempublikasikan identitas responden (UU No. 16 Tahun 1997 tentang Statistik) dengan kebutuhan demokrasi untuk mengkonsultasikan calon penerima Raskin dengan publik lokal. Ketika hasil pendataan rumah tangga miskin menimbulkan keresahan sosial-politik barulah pemerintah pusat secara serius meminta pemda melakukan langkah-langkah "pengamanan," antara lain melalui instruksi pembentukan posko pengaduan. Dalam hal ini pemda terposisikan seolah-olah sebagai "pemadam kebakaran".

Pada dasarnya, kesederhanaan birokrasi penyelenggaraan program Raskin yang diserahkan kepada Bulog dan pemerintah daerah merupakan kunci keefisienan pelaksanaan program ini. Persoalan kemudian muncul lebih karena kedua pelaksana tersebut adalah instansi yang para karyawannya biasa bekerja dengan pendekatan teknis, sementara kemiskinan merupakan persoalan yang berdimensi jamak dan memerlukan pendekatan sosial, ekonomi, dan politik secara komprehensif.

Yang seharusnya berhak menerima raskin sebanyak 313 RTS-PM, karena di Tahun 2013 menurut data PPLS 2011 yang dikelola TNP2K pagu raskin desa Sukorejo hanya 217 RTS-PM, 
sehingga untuk memenuhi jumlah 313 RTS-PM tersebut dari hasil Musyawarah Desa (Mudes) ditetapkan ada 2 (dua) kelompok penerima raskin yaitu Penerima Pokok dan Kelompok Gilir. Untuk penerima pokok pembagiannya setiap raskin datang mereka menerima raskin, sedangkan Kelompok Gilir pembagiannya 2 (dua) kali raskin datang mereka baru dapat dengan kartu pengambilan raskin yang berbeda warna. Adapun rincian Kelompok Penerima Raskin di Desa Sukorejo Kecamatan Sidayu Kabupaten Gresik sebagai berikut :

1. Kelompok pertama disebut dengan Penerima Pokok, dengan Kartu pengambilan raskin berwarna hijau sebanyak 121 RTS-PM, pagu $15 \mathrm{Kg}$ per RTS-PM per bulan, artinya setiap raskin datang di Kantor Desa (Titik Distribusi/Titik Bagi) kelompok penerima pokok ini setiap bulan raskin datang mereka menerima raskin.

2. Kelompok kedua disebut dengan Gilir 1, dengan kartu pengambilan raskin berwarna biru sebanyak 96 RTS-PM . Kelompok ini menerima raskin pada bulan pertama. Berikutnya pada bulan ketiga, artinya 2 (dua) kali raskin datang mereka baru menerima.

3. Kelompok ketiga disebut dengan Gilir 2, dengan kartu pengambilan raskin berwarna kuning sebanyak 96 RTS-PM.Kelompok ini menerima raskin pada bulan kedua.Berikutnya pada bulan keempat, sama dengan kelompok Gilir 1 bahwa 2 (dua) kali raskin datang baru menerima.

\section{Kejelasan implementor tentang Program Raskin}

Permasalahan yang muncul menyangkut pentargetan dan penyaluran Program Beras Miskin terkait dengan lemahnya sosialisasi program. Hasil wawancara penulis dengan Bapak Riadi, SE. Sebagai Kasi Pelayanan Publik Bulog Sub Divre I Gresik, menyatakan bahwa lemahnya sosialisasi terjadi di semua tahapan pelaksanaan, mulai dari proses pendataan hingga mekanisme pengaduan. Sosialisasi kepada masyarakat bisa dikatakan tidak dilakukan. Meskipun sosialisasi untuk jajaran Pemda dilakukan, namun agak terlambat dan informasinya hanya tentang rencana pendataan. Hal ini diperparah dengan tidak tersedianya petunjuk pelaksanaan program yang menyeluruh di tingkat Pemda. Bahkan beberapa surat yang terkait dengan pelaksanaan Raskin dari pemerintah pusat yang sebenarnya dapat dijadikan dasar hukum Pemda setempat, seperti Inpres, SK Menko Kesra dan SK Mendagri, terlambat datang atau bahkan tidak diterima. Di satu pihak, minimnya sosialisasi pada tahap pendataan dapat mengurangi munculnya moral hazard dalam penentuan target. Di pihak lain, kurangnya sosialisasi secara menyeluruh justru mendorong munculnya salah persepsi dan kecemburuan sosial.

Secara kelembagaan, di daerah tidak ada yang merasa bertanggung jawab untuk melakukan sosialisasi, sedangkan Kementerian Komunikasi dan Informasi (Menkominfo) sebagai penanggung jawab sosialisasi nasional hanya melakukan sosialisasi melalui media cetak dan media elektronik yang jangkauannya terbatas dan hanya dapat diakses oleh kalangan tertentu. Upaya penyebaran brosur tentang kriteria rumah tangga miskin pun, selain datangnya terlambat, jumlahnya terbatas, juga kurang informatif bagi masyarakat umum. Selain itu, kelembagaan yang menangani pengaduan dan pemantauan program juga tidak berjalan di semua wilayah.

Keberadaan posko dan mekanisme pengaduan yang tersedia tidak diinformasikan secara luas kepada masyarakat sehingga terjadi variasi jalur pengaduan. Adanya kesalahan sasaran (mistargeting) yang diperparah dengan sosialisasi yang tidak memadai, khususnya tentang kriteria target dan tujuan program, telah memicu munculnya ketidakpuasan masyarakat. Ketidakpuasan masyarakat diungkapkan dalam berbagai bentuk, mulai dari keluhan, protes atau demonstrasi, melakukan ancaman, hingga pengrusakan. Pengaduan yang berbentuk aksi protes dan ancaman biasanya ditangani oleh kepala desa/lurah dibantu oleh aparat keamanan/kepolisian. Di beberapa daerah aparat pemda kabupaten/kota dan kecamatan serta 
BPS juga turun tangan. Aksi protes dan ancaman dari masyarakat tersebut dapat diredam dengan:

1. Dibukanya pendaftaran susulan bagi masyarakat yang merasa berhak

2. Adanya kesediaan penerima Raskin untuk membagi sebagian bantuan kepada rumah tangga miskin lainnya

3. Ada pejabat yang menjanjikan bahwa pendaftar susulan akan menerima Raskin pada tahap berikutnya

Implementor/pelaksana program, dalam hal ini tim dari kelurahan, ketua RW dan ketua RT masing-masing sudah paham terhadap tugasnya dan mendukung Raskin. Sosialisasi Program Raskin adalah kegiatan penunjang program untuk memberikan informasi yang lengkap sekaligus pemahaman yang sama dan benar kepada seluruh pemangku kepentingan terutama kepada pelaksana, masyarakat umum dan khususnya Rumah Tangga Miskin penerima manfaat. Informasi dan pemahaman yang sama dan benar dimaksud meliputi latar belakang, kebijakan pemerintah, tujuan, sasaran, pengelolaan, pengorganisasian, pengawasan dan pelaporan serta hak-hak kewajibannya masing-masing.

Sosialisasi program Raskin diharapkan pelaksanaan di lapangan sejak awal dapat berjalan secara lancar, tertib, tepat waktu dan terencana sesuai ketentuan yang ditetapkan. Demikian pula, apabila dalam pelaksanaan program masih ditemui adanya indikasi penyimpangan pelaksanaan, seluruh pemangku kepentingan termasuk masyarakat umum perlu mengetahui atau mengadukan sekaligus penyelesaian masalahnya melalui jalur Unit Pengaduan Masyarakat (UPM) yang tersedia.

Sosialisasi program Raskin dapat dilakukan melalui berbagai cara yang efektif antara lain sebagai berikut:

1) Rapat Koordinasi

Rapat koordinasi diselengarakan diseluruh tingkatan mulai dari pusat, provinsi, kabupaten/kota sampai desa/kelurahan. Hal ini dimaksudkan untuk meningkatkan pemahaman berbagai instrumen yang diperlukan sehingga pelaksanaan program Raskin berjalan dengan baik. Sosialisasi di tingkat desa/kelurahan dilaksanakan melalui forum musyawarah desa/kelurahan yang telah ada, sebagai forum interaksi antar pelaksana dan masyarakat. Disamping itu, sosialisasi juga dilakukan pada saat pelaksanaan distribusi dan/atau forum pertemuan tingkat desa/kelurahan lainnya.

2) Media Massa

Sosialisasi melaui media massadimaksudkan untuk mempercepat dam memperluas jangkauan sasran sosialisasi. Sosialisasi melalui media massa dilakukan melalui media cetak antara lain koran, majalah maupun media elektronik seperti radio, televisi dan internet baik ditingkat nasional maupun daerah.

3) Media Lainnya

Sosialisasi juga dapat dilakukan dengan memanfaatkan media lainnya antara lain buklet, brosur, stiker, spanduk maupun forum keagamaan, budaya, arisan dan lain-lain yang dikembangkan dalam bahasa lokal maupun nasional.

Sosialisasi Raskin di Desa Sukorejo Kecamatan Sidayu dengan cara rapat koordinasi melalui musyawarah dengan melibatkan staf kelurahan, para ketua RW dan ketua RT, selanjutnya hasil dari musyawarah diinformasikan kepada warga melalui rapat RT.

Upaya-upaya yang dilakukan untuk menjaga agar program Raskin dapat berjalan dengan baik dan tepat sasaran, di RW II dengan membagi rata kepada setiap warga yang tidak mampu baik yang dapat kartu maupun yang tidak. Di RW III dengan membagi secara rata pada setiap warga dan bergilir menjadi yang bulan ini dapat, bulan depan belum tentu dapat, tergantung jumlah beras yang diterima.

Di RW IV dengan membagi secara rata kepada semua warga miskin yang dapat kartu setiap bulan sedangkan yang tidak dapat kartu hanya mendapatkan dua bulan sekali. Dari 
data tersebut diatas, dapat disimpulkan bahwa implementor cukup paham tugasnya masingmasing, sosialisasi juga berjalan dengan baik sesuai dengan yang diinginkan. Akan tetapi boleh dikatakan belum tepat sasaran karena warga yang tergolong mampupun mendapatkan Raskin.

Tabel. 4.12.

Rekapitulasi RTS-PM Kecamatan Sidayu Kabupaten Gresik Tahun 2015

\begin{tabular}{|c|c|c|c|c|}
\hline NO & KECAMATAN & DESA & $\begin{array}{c}\text { JUMLAH } \\
\text { RTS-PM }\end{array}$ & $\begin{array}{c}\text { JUMLAH } \\
\text { (RTSX15 Kg) }\end{array}$ \\
\hline & \multirow{22}{*}{ SIDAYU - 130} & ASEMPAPAK - 009 & 65 & 975 \\
\hline & & BUNDERAN - 013 & 50 & 750 \\
\hline & & GEDANGAN - 021 & 219 & 3285 \\
\hline & & GOLOKAN - 018 & 515 & 7725 \\
\hline & & KAUMAN - 014 & 9 & 135 \\
\hline & & KERTOSONO - 003 & 268 & 4020 \\
\hline & & LASEM - 002 & 225 & 3375 \\
\hline & & MOJOASEM - 008 & 46 & 690 \\
\hline & & MRIYUNAN - 010 & 142 & 2130 \\
\hline & & NGAWEN - OO6 & 216 & 3240 \\
\hline & & PENGULU - 015 & 34 & 510 \\
\hline & & PURWODADI - 012 & 146 & 2190 \\
\hline & & RACIKULON - 004 & 54 & 810 \\
\hline & & RACITENGAH - 005 & 106 & 1590 \\
\hline & & RANDUBOTO - 007 & 400 & 6000 \\
\hline & & SAMBIPONDOK - 019 & 63 & 945 \\
\hline & & SEDAGARAN - 016 & 65 & 975 \\
\hline & & SIDOMULYO - 011 & 43 & 645 \\
\hline & & SROWO - 017 & 111 & 1.665 \\
\hline & & SUKOREJO - 001 & 217 & 3255 \\
\hline & & WADENG - 020 & 579 & 8685 \\
\hline & & & 3573 & 53595 \\
\hline
\end{tabular}

Sumber : Sub Divre Surabaya Utara (Menunjuk Surat Deputi Menko Kesra Bidang Perlindungan Sosial dan Perumahan Rakyat Kementerian Koordinator Bidang Kesejahteraan Rakyat, ditindaklanjuti Surat Gubernur Jawa Timur Nomor : 518/2453/021/2012

Tabel.4.13.

Alokasi Pagu Raskin di Provinsi Jawa Timur Tahun 2015

\section{Kendala Program Raskin di Desa Sukorejo Kecamatan Sidayu Kabupaten Gresik}

Pemerintah mengakui ada enam titik kritis atau kelemahan yang harus dibenahi dalam pengucuran bantuan Raskin tahap pertama. Keenam titik kritis tersebut meliputi:

1. Proses pencacahan atau pendataan rumah tangga miskin;

2. Proses penetapan kategori rumah tangga miskin;

3. Proses pembagian kartu;

4. Proses penyaluran bantuan;

5. Proses sosialisasi;

6. Proses penanganan pengaduan;

Sedangkan dari hasil wawancara dengan informan di lapangan, kendala yang dihadapi program Raskin di Desa Sukorejo Kecamatan Sidayu Kabupaten Gresik ini, antara lain : 
1. Penyimpangan kualitas beras yang jelek artinya berbau, diikuti dengan penyimpangan harga beras yang seharusnya Rp 1600/kg menjadi Rp.2000/kg.

2. Pembagian kartu Raskin mengandung unsur subyektifitas sehingga tidak tepat sasaran serta dibagi menjadi penerima pokok, gilir 1 Dan gilir 2 serta gilir 3.

3. Data RTS (Rumah Tangga Sasaran) dari BPS tidak valid dan tertutup, sehingga ada warga miskin tidak dapat kartu dan yang mampu dapat, sehingga menimbulkan ancaman, tuntutan dan kecemburuan sosial.

4. Kebijakan ketua RW dan RT bahwa semua warga dapat beras (bagito) mengakibatkan pembagian Raskin tidak sesuai dengan aturan (15 kg/RTS), hal ini diakibatkan kurang sadarnya warga mampu yang seharusnya tidak dapat tetapi menuntut untuk mendapatkan bagiannya.

5. Pembayaran Raskin oleh RTS yang sering tertunda (hutang).

\section{SIMPULAN}

\section{Implementasi Kebijakan Raskin}

\section{a. Isi Kebijakan}

1. Pemahaman kepentingan RTS

dalam menentukan sasaran ditemui adanya kesalahan sasaran (mistargeting) meskipun dalam tingkat yang relatif rendah, sering tidak tepat karena mementingkan kelompok-kelompok tertentu (subyektifitas), pembagian jatah Raskin tidak sesuai dengan Kebijakan Program Raskin yaitu dengan membagi rata pada semua warga.

2. Manfaat Raskin yang diterima oleh RTS

Manfaat dari Program Raskin ini, dinilai sangat kurang akibat adanya "Bagito", sehingga belum dapat mengurangi beban pengeluaran rumah tangga miskin.

3. Perubahan kondisi RTS setelah mendapatkan Raskin

Sebagian besar RTS program Raskin merasa bahwa pembagian beras kepada warga miskin mempunyai manfaat minimal kebutuhan dalam satu minggu.

4. Ketepatan sasaran Program Raskin

Ketidaktepatan sasaran didukung dengan data BPS yang tidak valid, karena pendataannya tidak berkoordinasi dengan RT dan RW setempat (bersifat tertutup).

5. Kejelasan implementor tentang Program Raskin Implementor cukup paham tugasnya masing-masing, sosialisasi juga berjalan dengan baik sesuai dengan yang diinginkan. Akan tetapi belum tepat sasaran karena warga yang tergolong mampu mendapatkan Raskin.

6. Kualitas dan kuantitas SDM sebagai implementor

Bulog sebagai pelaksana teknis pencairan beras tidak hanya terpaut dengan unsur kapasitas teknis saja, selain itu unsur tanggung jawab dan komitmen yang di tingkat Kelurahan, RW hingga RT tidak kalah penting artinya.

b. Lingkungan Kebijakan

1. Kekuasaan, kepentingan dan strategi implementasi Program Raskin cukup mampu mewujudkan kehendak dan harapan sehingga dapat berjalan dengan lancar karena sesuai dengan kondisi masyarakatnya.

2. Karakteristik rezim yang berkuasa, Strategi distribusi Raskin tidak menuai protes karena kebijakan rezim yang berkuasa berdasarkan kesepakatan bersama.

3. Tingkat kepatuhan dan responsivitas kelompok sasaran Respon warga baik dan antusias serta mematuhi strategi distribusi Raskin. Meskipun ada beberapa warga yang masih hutang. 


\section{Kendala-kendala yang dihadapi dalam Implementasi Program Raskin.}

a. Adanya enam titik kritis dalam proses pelaksanaan Program Raskin yang diakui pemerintah yaitu : proses pencacahan atau pendataan rumah tangga miskin,proses penetapan kategori rumah tangga miskin, proses pembagian kartu, proses penyaluran bantuan, proses sosialisasi, proses penanganan pengaduan.

b. Penyimpangan kualitas beras diikuti dengan penyimpangan harga beras.

c. Pembagian kartu Raskin mengandung unsur subyektifitas sehingga tidak tepat sasaran.

d. Data RTS tidak valid dan tertutup, sehingga ada warga miskin tidak dapat kartu dan yang mampu dapat.

e. Kebijakan ketua RW dan RT untuk Bagito.

f. Pembayaran Raskin oleh RTS yang sering tertunda (hutang).

\section{Saran Pendistribusian Ke depan agar Lebih Baik}

Pengelolaan Raskin ke depan mengacu pada indikator kinerja Raskin terdapat enam tepat, yaitu:

1. Tepat sasaran penerima manfaat, supaya penyempurnaan kartu penerima program harus dikoordinasikan dengan RT, RW dan Kelurahan penerima Raskin sehingga transparan dan akuntabel.

2. Tepat jumlah, jumlah Raskin yang dibagikan ke masyarakat seharusnya sesuai dengan peraturan yang ditetapkan oleh pemerintah. Saat ini (tahun 2013) ditetapkan $15 \mathrm{~kg}$ per RTS per bulan, selama 12 bulan.

3. Tepat Harga, harga Raskin yang dibebankan pada masyarakat seharusnya sesuai dengan peraturan yang ditetapkan oleh pemerintah. Saat ini (tahun 2013) ditetapkan Rp. 1.600 per kilogram.

4. Tepat waktu, jadwal distribusi ke masyarakat, sebaiknya sesuai dengan waktu yang dijadwalkan, oleh karena itu dalam hal ini, pemerintah harus membantu operasional penyaluran raskin hingga sampai ke desa yang dituju .

5. Tepat Administrasi, pembayaran Raskin yang tertunda (hutang) harus didesain dengan mempertimbangkan karakter perilaku masyarakat penerima Raskin misalnya dengan cara menabung sesuai kemampuan yang dikoordinir oleh tim yang ditunjuk RT, RW atau Kelurahan.

6. Tepat Kualitas, perlu ditingkatkan terutama terkait dengan kualitas beras dimana kualitas beras ini masih sangat rendah, ada kesan bahwa beras yang diberikan sebetulnya sudah tidak layak untuk dimakan. Bulog sebagai penanggungjawab

\section{REFERENSI}

Arikunto, Suharsimi. 2002. Prosedur Penelitian Suatu Pendekatan Penelitian. Jakarta: Rineka Cipta

Chamsah, Bachtiar, 2007, http:// www.setneg.go.id/index.php? Option = com_content \& task=view\&id $=216 \&$ Itemid $=76$. Diakses 29 Juni 2014

Ekowati, Lilik. 2005. Perencanaan, Implementasi dan Evaluasi atau Program. Surakarta : Pustaka Cakra

http : // www.kompas.com / kompas-cetak /0402/10/ ekonomi/ 84716. Diakses 29 Juni 2014

Islamy, Irfan. 2000. Prinsip-Prinsip Perumusan Kebijaksanaan Negara. Jakarta: Bumi Aksara

Kementrian Koordinator Bidang Kesejahteraan Rakyat. 2013. Pedoman Umum Beras Untuk Rumah Tangga Miskin. Jakarta

Muhammad, Abdulkadir. 2007. Metodologi Penelitian.Bandung: Citra Aditya 
Nawawi, Hadari. 2003. Metode Penelitian Bidang Sosial. Yogyakarta: Gajah Mada University Press

Nugroho, Riant. 2003. Kebijakan Publik, Formulasi, Implementasi, dan Evaluasi. Jakarta: PT Elex Media Komputindo

Petunjuk Pelaksanaan Subsidi Beras Bagi Masyarakat Berpendapatan Rendah 2013 (Juklak Raskin) Provinsi Jawa Timur.

Siagian, Sondang. 1983. Administrasi Pembangunan. Jakarta: CV Haji Masagung

Soekanto, Soejono. 1997. Pengantar Metodologi Penelitian. Jakarta: PT Raja Grafindo Persada

Soetomo. 2006. Strategi-strategi Pembangunan Masyarakat. Yogyakarta: Pustaka Pelajar.

Subarsono, AG. 2005. Analisis Kebijakan Publik. Konsep, Teori, dan Aplikasi. Yogyakarta: Pustaka Pelajar

Surachmad, Winarno. 1978. Dasar dan Teknik Research, Pengantar Metodologi Ilmiah. Bandung : Tarsito.

Surat Gubernur Jawa Timur Nomor : 518/245531/021/2012 tanggal 28 Desember 2012 tentang PAGU Raskin alokasi pagu Raskin Provinsi Jawa Timur Tahun 2013.

Thoha, Miftah. 2002. Dimensi-Dimensi Prima Ilmu Administrasi Negara. Jakarta: PT Raja Grafindo Persada

Undang-undang No. 11 Tahun 2013.

Wahab, Abdul. 2004. Analisis Kebijakan dari Formula Keimplementasian Kebijakan Negara. Jakarta : Bumi Aksara

Wibawa, Samudra. 1994. Evaluasi Kebijakan Publik. Jakarta: PT Grafindo Persada. www.bulog.co.id. Diakses 29 Juni 2014

Yashin, Sulcahn. 1997. Kamus Lengkap Bahasa Indonesia (KBI-Besar) serta Ejaan Yang Disempurnakan Dan Kosa Kata Baru. Surabaya: Amanah 